\title{
Hubungan antara Komponen Retensi Pegawai dengan Kinerja Perawat Non-PNS
}

\author{
The Correlation between Employee Retention Components with Non-State Employee \\ Nurse Performance \\ Pratiwi Nurullaili 1*, Yennike Tri Herawati ${ }^{1}$, Sri Utami ${ }^{1}$ \\ 1) Bagian Administrasi dan Kebijakan Kesehatan \\ Fakultas Kesehatan Masyarakat Universitas Jember \\ pratiwinurullaili@gmail.com \\ https://doi.org/10.29080/jhsp.v3i1.138
}

\section{Kata Kunci}

Retensio Pegawai Pegawai Non-PNS Kinerja Perawat

\begin{abstract}
Abstrak
Retensi Pegawai adalah kemampuan yang dimiliki sebuah organisasi dalam mempertahankan dan meningkatkan loyalitas pegawai potensialnya. Retensi yang lemah dapat mempengaruhi keterikatan pegawai dengan organisasinya, menurunnya kinerja pegawai, dan meningkatnya turnover pegawai. Tujuan dari penelitian ini untuk menganalisis hubungan antara komponen retensi pegawai dengan kinerja perawat nonPNS di RSD Balung tahun 2018. Jenis penelitian ini adalah analitik dengan desain penelitian cross sectional, jumlah populasi sebanyak 64 orang, dan jumlah sampel sebanyak 55. Penentuan sampel dilakukan dengan teknik simple random sampling. Data diperoleh dengan wawancara menggunakan kuesioner dan studi dokumentasi dokumen asuhan keperawatan. Data yang diperoleh berskala ordinal dan dianalisis menggunakan Spearman rho dengan $\alpha=0,05$. Hasil penelitian menyatakan tidak ada hubungan antara komponen organisasi dan manajemen $(\rho=0,134>\alpha)$, hubungan kerja $(\rho=0,701>\alpha)$, pelatihan dan pengembangan $(\rho=0,126>\alpha)$, dan kebijakan organisasi dan praktiknya $(\rho=0,207>\alpha)$ dengan kinerja perawat non-PNS di RSD Balung. Sedangkan analisis komponen desain pekerjaan dan keberlanjutannya $(\rho=0,022<\alpha)$ dan komponen penghargaan $(\rho=0,001<\alpha)$ menunjukan adanya hubungan dengan kinerja perawat non-PNS di RSD Balung.
\end{abstract}

\begin{abstract}
Employee retention is an organization's ability to maintain and improve the loyalty of their potential employees. Weak retention will affect employee engagement with the organization, decrease performance, and increase employee turnover. The purpose of this study was to analyze the correlation between component of employee retention with nonstate employee nurses performance in Balung State Hospital 2018. The type of research is analytic with cross sectional design. The total population is 64 people and number of samples is 55. The samples were determined by using simple random sampling technique. Data were gained by interview using questionnaire and documentation study of nursing care document. The data which gained has ordinal scale and analyzed use Spearman rho test with $\alpha=0.05$. The results of the study stated that there is not correlate between organizationals and management factors $(\rho=0,134>\alpha)$, colleague relationship $(\rho=0,701$ $>\alpha)$, career training and development $(\rho=0,126>\alpha)$, and employer policies and practices $(\rho=0,207>\alpha)$ with non-state employee nurses performance in Balung State Hospital. While, the analysis of job design and work-life $(\rho=0,022<\alpha)$ and rewards factor $(\rho=$ $0,001<\alpha$ ) shows positive correlation with non-state employee nurses performance in Balung State Hospital result.
\end{abstract}

\section{Pendahuluan}

Rumah Sakit merupakan salah satu perwujudan Undang-Undang Dasar Negara Republik Indonesia Tahun 1945 yaitu sebagai pemenuhan hak masyarakat terhadap pelayanan kesehatan. Pelayanan kesehatan di Rumah Sakit harus diupayakan sebaik-baiknya demi tercapainya derajat kesehatan masyarakat yang setinggi-tingginya. Secara kuantitas, telah terjadi peningkatan jumlah RS baik di tingkat nasional maupun di Kabupaten Jember. Jumlah rumah sakit yang semakin meningkat membuat setiap rumah sakit saling 
bersaing untuk mendapatkan pelanggan (1). Oleh karena itu, diperlukan strategi bagi Rumah Sakit agar mutu atau kualitas pelayanan kesehatannya terjamin secara berkelanjutan.

Mutu pelayanan kesehatan adalah kesesuaian pelayanan kesehatan dengan standar profesi dengan memanfaatkan sumber daya yang tersedia sehingga dapat memenuhi semua kebutuhan pasien dan mengoptimalkan derajat kesehatan (2). Pengukuran mutu pelayanan Rumah Sakit dapat dilakukan secara langsung dengan menggunakan variabel proses berupa kinerja pegawainya. Menurut Amstrong dan Baron, kinerja merupakan hasil pekerjaan yang mempunyai hubungan kuat dengan tujuan strategis organisasi, kepuasan konsumen, dan memberikan kontribusi pada ekonomi (3).

Dalam upaya menjamin kualitas kinerja pegawai, pihak manajemen Rumah Sakit juga harus menjamin variabel inputnya. Di antara variabel input yang dimiliki Rumah Sakit, Sumber Daya Manusia menempati peran sentral dalam efektivitas proses pelayanan kesehatan yang diberikan. Perawat menjadi profesi yang memiliki peran paling besar dalam menentukan output berupa capaian kepuasan pasien terhadap pelayanan kesehatan. Sebagaimana menurut Hafid, perawat adalah sumber daya rumah sakit yang paling banyak berinteraksi dengan pasien (4). Penelitian Netti et al. yang dilakukan di Unit Rawat Inap Puskesmas Kartasura pun berkesimpulan bahwa kinerja perawat memiliki hubungan dengan pencapaian kepuasan pasien (5).

Telah dipahami oleh banyak manajemen Rumah Sakit bahwa para profesional di Rumah Sakit adalah aset utama namun juga berpotensi menjadi masalah utama sehingga harus dikelola secara arif dan bijaksana (6). Hasil temuan Gallup Organization pada tahun 2013 mengungkapkan bahwa 92\% pegawai di Indonesia menunjukkan keterikatan (employee engagement) yang lemah dengan organisasi pemberi kerja (7). Keterikatan Pegawai (employee engagement) merupakan keadaan psikologis atau afektif (dapat digambarkan melalui komitmen, keterikatan, dan lain-lain) yang membangun kinerja atau sikap (8). Karyawan yang memiliki engagement rendah dengan perusahaan cenderung memiliki keinginan untuk berpindah atau keluar dari perusahaan (turnover) (9).

Ada kalanya pergantian karyawan membawa dampak positif, namun sebagian besar pergantian karyawan membawa pengaruh negatif terhadap perusahaan, baik dari segi biaya maupun dari segi hilangnya waktu dan kesempatan untuk memanfaatkan peluang (10). Turnover mengakibatkan perusahaan, harus menanggung biaya dan menyediakan waktu kembali untuk melakukan rekrutmen, seleksi, dan training agar mendapatkan karyawan yang memiliki kualitas serupa dengan karyawan yang keluar dari perusahaan (11). Menindaklanjuti hal tersebut, maka Rumah sakit perlu melakukan upaya untuk menekan turnover, meminimalisasi hasrat untuk berhenti, dan menciptakan keterikatan yang baik pada pegawainya, khususnya dalam hal ini kepada perawat sebagaimana merupakan profesi yang paling berpengaruh terhadap pencapaian kepuasan pasien.

Upaya yang dapat dilakukan Rumah Sakit dalam menjamin kondisi fisik, mental, dan sikap agar loyalitas dan produktifitas perawat sebagai komponen input tetap terjaga adalah melalui retensi pegawai. Retensi pegawai (employee retention) merupakan upaya perusahaan untuk mempertahankan karyawan potensial yang dimiliki perusahaan untuk tetap loyal terhadap perusahaan (12).

Retensi karyawan lemah pada suatu organisasi dapat ditandai dengan tingkat turnover pegawainya (6). Berdasarkan data yang diperoleh dari Sub Bagian Kepegawaian dan Diklat RSD Balung, sejak 2016 hingga 2017 persentase turnover perawat di RSD Balung mengalami peningkatan dan seluruhnya dialami oleh perawat berstatus non-PNS. Studi pendahuluan lebih lanjut dilakukan dengan menyebarkan angket kepada perawat non-PNS dan mendapati $62,5 \%$ responden memiliki hasrat untuk mengundurkan diri dari pekerjaannya (turnover intention). Hasil tersebut mengindikasikan employee engagement yang kurang baik dan secara tidak langsung akan berdampak terhadap performa kerja yang tidak optimal dan terjadinya turnover pegawai.

Berlandaskan hal tersebut, peneliti merasa perlu dilakukan penelitian untuk menganalisis komponen retensi apa saja yang berhubungan dengan kinerja perawat non-PNS di RSD Balung tahun 2018.

\section{Metode Penelitian}

Jenis penelitian ini adalah penelitian analitik dengan desain penelitian cross sectional Penelitian berlokasi di RSD Balung Kabupaten Jember. Populasi dari penelitian adalah seluruh perawat berstatus NonPNS yang berjumlah 64 orang. Jumlah sampel yang digunakan dihitung menggunakan rumus Lemeshow dan didapatkan jumlah 55 orang responden yang selanjutnya ditentukan menggunakan teknik simple random sampling.

Data diperoleh melalui wawancara menggunakan kuesioner dan studi dokumentasi dokumen asuhan keperawatan. Kemudian data dianalisis menggunakan uji kolmogorov-smirnov dan diketahui data tidak memenuhi asumsi distribusi normal. Untuk mengetahui hubungan komponen retensi dengan kinerja perawat non-PNS, dilakukan analisis menggunakan uji Spearman rho. 


\section{Hasil Penelitian}

Berdasarkan penelitian yang dilakukan, dapat diidentifikasi penilaian komponen retensi pegawai oleh perawat non-PNS sebagai berikut:

1. Komponen Organisasi dan Manajemen mendapatkan penilaian baik $(67,27 \%)$

2. Komponen Hubungan Kerja mendapatkan penilaian baik $(74,55 \%)$

3. Komponen Desain Pekerjaan dan Keberlanjutan Pekerjaan mendapatkan penilaian kurang baik $(67,27 \%)$

4. Komponen Penghargaan mendapatkan penilaian cukup baik $(70,91 \%)$

5. Komponen Pelatihan dan Pengembangan mendapatkan penilaian cukup baik $(52,73 \%)$

6. Komponen Kebijakan Organisasi dan Praktiknya mendapatkan penilaian baik $(52,73 \%)$ Adapun distribusi penilaian responden lebih lengkapnya tertera pada grafik 1.

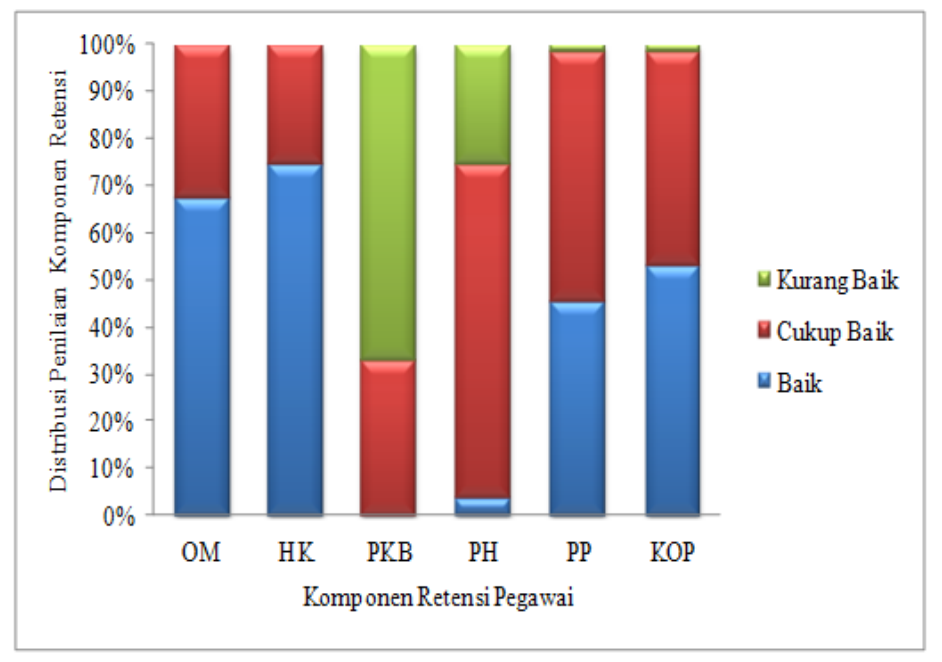

Gambar 1. Distribusi Responden Berdasarkan Penilaian Komponen Retensi Pegawai

Sedangkan penilaian kinerja perawat mendapatkan penilaian sebagai berikut.

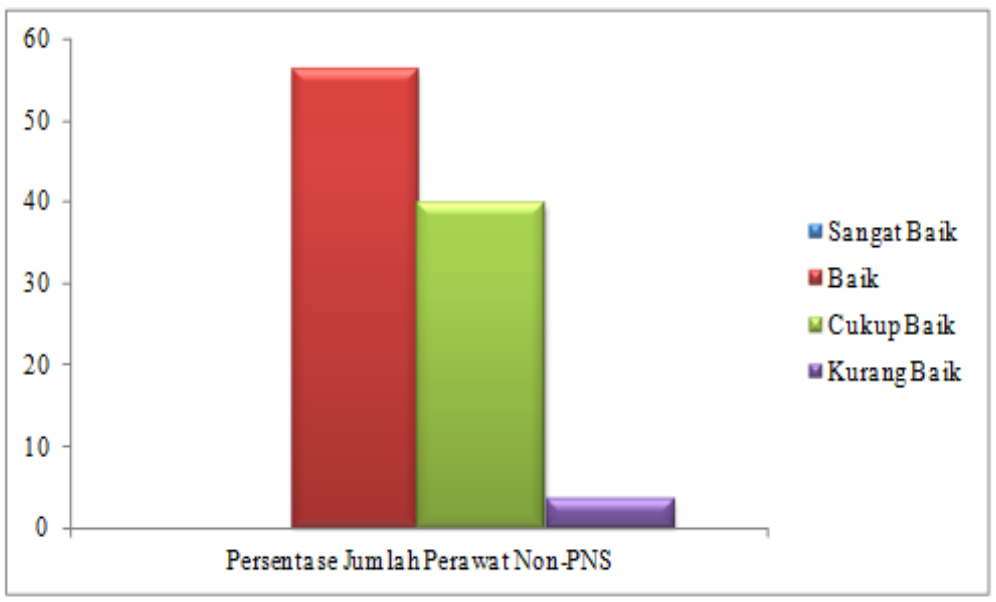

Gambar 2. Distribusi Kinerja Perawat Non-PNS

Sebanyak 56,36\% dari 55 responden memiliki kinerja yang baik. Sebanyak 40\% responden melakukan pekerjaannya dengan cukup baik. Sedangkan sisanya, yaitu sebanyak 3,64\%, memiliki kinerja yang kurang baik. 
Analisis terhadap komponen retensi pegawai mendapatkan hasil sebagai berikut.

Tabel 1. Output Uji Statistik Hubungan Komponen Retensi Dengan Kinerja Perawat Non-PNS

\begin{tabular}{|c|c|c|c|c|}
\hline \multicolumn{3}{|c|}{ Spearman Rho Test } & \multirow{2}{*}{$\begin{array}{r}\text { Komponen Retensi } \\
1,000\end{array}$} & \multirow{2}{*}{$\begin{array}{l}\text { Kinerja } \\
\text { 205 }\end{array}$} \\
\hline 1. & $\mathrm{OM}$ & Correlation Coefficient & & \\
\hline & & Sig. (2-tailed) & . & ,134 \\
\hline & & $\mathrm{N}$ & 55 & 55 \\
\hline \multirow{3}{*}{\multicolumn{2}{|c|}{ 2. $\mathrm{HK}$}} & Correlation Coefficient & 1,000 &, 503 \\
\hline & & Sig. (2-tailed) & . & ,701 \\
\hline & & $\mathrm{N}$ & 55 & 55 \\
\hline \multirow{3}{*}{\multicolumn{2}{|c|}{ 3. $\mathrm{PKB}$}} & Correlation Coefficient & 1,000 & ,309* \\
\hline & & Sig. (2-tailed) & . & 022 \\
\hline & & $\mathrm{N}$ & 55 & 55 \\
\hline \multirow{3}{*}{\multicolumn{2}{|c|}{ 4. $\mathrm{PH}$}} & Correlation Coefficient & 1,000 &, $427^{* *}$ \\
\hline & & Sig. (2-tailed) & . & 001 \\
\hline & & $\mathrm{N}$ & 55 & 55 \\
\hline \multirow{3}{*}{\multicolumn{2}{|c|}{ 5. $\quad \mathrm{PP}$}} & Correlation Coefficient & 1,000 & ,209 \\
\hline & & Sig. (2-tailed) & . & ,126 \\
\hline & & $\mathrm{N}$ & 55 & 55 \\
\hline \multirow{3}{*}{\multicolumn{2}{|c|}{ 6. KP }} & Correlation Coefficient & 1,000 &,- 173 \\
\hline & & Sig. (2-tailed) & . & ,207 \\
\hline & & $\mathrm{N}$ & 55 & 55 \\
\hline
\end{tabular}

1. Tidak ada hubungan antara komponen organisasi dan manajemen dengan kinerja perawat non-PNS di RSD Balung

2. Tidak ada hubungan antara hubungan kerja dengan kinerja perawat non-PNS di RSD Balung

3. Ada hubungan desain pekerjaan dan keberlanjutannya dengan kinerja perawat non-PNS di RSD Balung dengan koefisen korelasi 0,309

4. Ada hubungan antara komponen penghargaan dengan kinerja perawat non-PNS di RSD Balung dengan koefisien korelasi 0,427

5. Tidak ada hubungan antara komponen pelatihan dan pengembangan dengan kinerja perawat non-PNS di RSD Balung

6. Tidak ada hubungan kebijaan organisasi dan praktiknya dengan kinerja perawat non-PNS di RSD Balung

\section{Pembahasan}

a. Komponen Organisasi dan Manajemen, Hubungan Kerja, Pelatihan dan Pengembangan, serta Kebijakan Organisasi dan Praktiknya dengan Kinerja Perawat Non-PNS

Keempat komponen retensi pegawai yaitu organisasi dan manajemen, hubungan kerja, pelatihan dan pengembangan, serta kebijakan organisasi dan praktiknya tidak memiliki hubungan terhadap capaian Kinerja dari Perawat Non-PNS di RSD Balung. Komponen organisasi dan manajemen yang dimaksud dalam penelitian ini meliputi visi, misi, target operasional, reputasi dan eksistensi organisasi, keefektifan manajemen, dan kepemimpinan yang berjalan di dalamnya. Kinerja responden tidak dipengaruhi oleh komponen organisasi dan manajemen karena responden menganggap kesempatan untuk bekerja di luar RSD Balung kecil. Selain itu, jumlah rumah sakit yang tidak cukup banyak secara kuantitas di wilayah selatan Kabupaten Jember, menjadikan rumah sakit milik pemerintah daerah ini tetap menjadi pilihan masyarakat di wilayah tersebut.

Penelitian ini menunjukkan sebagian besar responden (67,27\%) mengungkapkan komponen organisasi dan manajemen RSD Balung telah berjalan dengan baik. Responden menyatakan RSD Balung telah memiliki tujuan dan target operasional yang jelas serta dianggap telah mampu bersaing dalam dunia pelayanan kesehatan. Tanpa menghilangkan kelemahannya, masyarakat cenderung memilih rumah sakit pemerintah karena memiliki kelebihan yang tidak dimiliki rumah sakit swasta, yaitu harga atau tarif yang relatif lebih murah (3). 
Sebanyak 67,27\% responden mengungkapkan manajemen belum pernah melakukan evaluasi terhadap kinerja perawat. Hal ini dapat mengakibatkan jalannya suatu kegiatan pelayanan tidak sesuai dengan tujuan awal karena bentuk pengawasan yang kurang. Bentuk pengawasan di dalam dunia pelayanan terbagi menjadi dua yaitu pemantauan (monitoring) dan evaluasi. Dalam hal monitoring, Kepala Ruang masih perlu meningkatkan upayanya menimbang kelengkapan asuhan keperawatan yang tampak masih kurang sesuai dengan standar asuhan keperawatan Persatuan Perawat Nasional Indonesia (PPNI). Sedangkan dalam evaluasi, diperlukan perencanaan dan pengorganisasian secara lebih terperinci, melibatkan seluruh bagian baik manajemen maupun tenaga profesional sehingga evaluasi kinerja dapat terlaksana dan terjamin keberlanjutannya dengan periode pelaksanaan minimal satu tahun sekali.

Dalam hal kepemimpinan, responden menilai telah cukup transformatif dan manajemen dianggap telah berlangsung dengan efektif. RSD Balung harus terus berbenah diri dengan menciptakan iklim kerja yang kondusif dan budaya kerja yang baik sehingga mampu beradaptasi dengan kebutuhan masyarakat akan fasilitas kesehatan di masa yang akan datang oleh karenanya, RSD Balung harus memiliki figur pemimpin yang transformatif, yang mau membuka diri akan perkembangan yang terjadi, visioner, dan inovatif.

Hubungan kerja adalah hubungan yang terjalin dalam pekerjaan. Hubungan kerja dalam penelitian ini meliputi hubungan antara perawat dengan rekan sesama perawat, hubungan perawat dengan atasannya yaitu kepala ruangan dan pimpinan lainnya, serta hubungan dengan profesi lain yang terkait.

Responden mengungkapkan adanya hubungan kerja yang baik antar perawat maupun dengan pegawai berprofesi yang berbeda dapat menciptakan kolaborasi tim yang baik dalam mewujudkan kesembuhan dan kepuasan pasien. Mickan mengungkapkan, peningkatan terhadap koordinasi perawatan, penggunaan layanan perawatan kesehatan yang efisien, peningkatan kepuasan kerja di dalam anggota tim, dan kepuasan pasien yang lebih tinggi adalah keuntungan dari keberadaan tim yang efektif (13). Namun demikian, terdapat kecenderungan bagi individu untuk mengurangi usahanya atau kinerjanya jika bekerja dengan orang lain atau yang disebut social loafing (3). Tidak ditemukannya hubungan antara hubungan kerja dengan kualitas kerja perawat non-PNS dapat disebabkan oleh kurangnya tantangan dan apresiasi antar pegawai dalam pekerjaan sekalipun komunikasi dirasa telah berjalan secara efektif dan kondusif untuk bekerja sehingga hubungan ker-ja tidak menjadi komponen yang mampu memicu atau memotivasi kinerja perawat non-PNS.

Dalam komponen pelatihan dan pengembangan pegawai, responden mengungkapkan manajemen rumah sakit kerap memberikan pelatihan. Namun demikian, pelaksanaan pelatihan di RSD Balung masih belum diiringi dengan upaya pengembangan pegawainya. Pengembangan sumber daya manusia adalah upaya yang dilakukan manajer atau pimpinan untuk mengembangkan kemampuan bawahannya sehingga didapatkan motivasi kerja pegawai yang berkelanjutan serta membentuk lingkungan kerja dengan moral dan standar yang tinggi. Hal ini menyebabkan adanya keterbatasan bagi perawat non-PNS untuk mengaktualisasikan dan mengembangkan kemampuan yang dimilikinya. Dapat dikatakan, sebaik apapun pelatihan yang diberikan tidak dapat teraktualisasikan dengan baik oleh perawat non-PNS dikarenakan sarana pengembangan yang kurang memadai.

Pemberian pelatihan tanpa diiringi dengan upaya pengembangan sumber daya manusia akan menyebabkan pegawai, dalam penelitian ini adalah perawat non-PNS, tidak merasa tertantang dalam menunjukkan peningkatan performa kerjanya. Menurut Wibowo, terdapat empat taktik dalam upaya pengembangan sumber daya manusia, yaitu mendesain ulang pekerjaan, pendelegasian, pelatihan keterampilan, dan pengembangan karier (3).

Sedangkan ketiadaan hubungan antara komponen kebijakan organisasi dan praktiknya dengan kinerja perawat non-PNS dapat disebabkan oleh tidak berjalannya peraturan di RSD Balung yang dianggap masih lemah konsistensinya sehingga dengan ada atau tidaknya peraturan yang telah dibuat, dirasakan tidak berpengaruh terhadap keberadaan perawat non-PNS dan lebih lanjut belum mampu mempengaruhi kualitas kerja perawat non-PNS. Menurut Mathis dan Jakcson, kebijakan organisasi harus dibuat secara wajar, konsisten, dan tegas dalam tindakan pendisiplinannya. Kebijakan organisasi dan praktik menurut Mathis dan Jackson tersebut bersifat mengikat terhadap pegawainya, jika dirasa tidak berjalan dengan baik akan meningkatkan keinginan pegawai untuk memilih pekerjaan di tempat lain atau dengan kata lain, komitmen untuk bekerja di organisasi (komitmen organisasional) tersebut menurun (14).

b. Hubungan Komponen Desain Pekerjaan dan Keberlanjutan Pekerjaan dan Komponen Penghargaan dengan Kinerja Perawat Non-PNS

Hasil penelitian ini menunjukkan adanya hubungan antara desain pekerjaan dan keberlanjutan pekerjaan terhadap kinerja perawat non-PNS di RSD Balung Kabupaten Jember Tahun 2018. Dengan koefisien korelasi sebesar 0,309, dapat dinyatakan bahwa kekuatan hubungan antara sub varibel desain pekerjaan dan keberlanjutannya dengan variabel kinerja perawat rendah. Artinya, untuk saat ini intervensi dalam hal desain pekerjaan dan keberlanjutan pekerjaan akan cukup mempengaruhi 
kualitas kinerja perawat non-PNS di RSD Balung. Semakin baik desain pekerjaan dan semakin jelas dan objektif peluang atau prospek karier bagi perawat non-PNS di masa mendatang diyakini akan meningkatkan kinerja perawat non-PNS tersebut.

Standar asuhan keperawatan perlu disosialisasikan kembali pada perawat sehingga dapat berjalan sesuai standar yang diharapkan. Penunjukan perawat dengan prestasi unjuk kerja terbaik dari setiap unit/ruangan dapat memacu kinerja perawat karena mendapat apresiasi atau pengakuan, alternatif ini juga dapat memberikan manfaat berupa adanya role model bagi rekan kerjanya sehingga standar kinerja perawat yang diharapkan dapat divisualisasikan. Penegakan aturan juga diperlukan untuk mendukung perawat non-PNS bekerja secara optimal pada jobdesc masing-masing. Selain itu, beban kerja dan jumlah perawat di setiap ruangan dapat dipertimbangkan kembali agar beban kerja sesuai dengan kemampuan tim di setiap ruangan. Pengembangan jobdesc juga dapat dilakukan sesuai kompetensi perawat non-PNS mempertimbangkan beban kerja yang telah dimiliki dengan tujuan untuk memberikan wadah bagi perawat non-PNS dalam aktualisasi dan pengembangan skill-nya sehingga tercapai kepuasan kerja.

Adapun yang dimaksud keberlanjutan pekerjaan adalah peluang karier yang dimiliki pegawai di masa yang akan datang (7). Berbeda dengan pegawai PNS, pegawai non-PNS tidak memiliki hak untuk menduduki jabatan, kecuali sebagai Ketua Tim di setiap ruangan. Perawat non-PNS wajib memperbarui kontraknya secara berkala setiap akhir tahun. Saat ini, perawat non-PNS di RSD Balung cenderung bertahan bekerja di RSD Balung dengan harapan akan mendapatkan promosi menjadi PNS oleh pemerintah di waktu yang akan datang. Akan tetapi hal ini berbenturan dengan Undang-Undang Nomor 5 Tahun 2014 tentang Aparatur Sipil Negara (ASN) bahwa pemerintah tidak dapat mengangkat secara langsung pegawai non-PNS yang terdapat pada instansi pemerintah, melainkan harus melalui proses seleksi sesuai kompetensi yang diperlukan (15). Dengan demikian, perawat non-PNS harus dapat memastikan kinerja yang baik dan sesuai standar untuk mengurangi adanya resiko Pemutusan Hubungan Kerja (PHK) dan didapatkannya perpanjangan kontrak kerja di periode yang akan datang.

Selain itu, analisis SPSS dari penelitian ini menunjukkan adanya hubungan antara komponen penghargaan atau apresiasi dengan kinerja perawat non-PNS di RSD Balung. Dengan koefisien korelasi sebesar 0,427, hubungan antara sub variabel penghargaan dengan kinerja perawat non-PNS di RSD Balung dapat dikatakan cukup kuat. Artinya, intervensi dalam hal pemberian penghargaan atas kinerja perawat diyakini akan meningkatkan kualitas performa kerja pada perawat tersebut. Semakin perawat mendapatkan rasa layak atas apresiasi yang diberikan pihak rumah sakit, semakin perawat merasa fair dan mendapat pengakuan atas kontribusinya, maka perawat akan menguatkan komitmennya untuk bekerja lebih produktif di rumah sakit yang menaunginya.

Berdasarkan penelitian yang dilakukan, responden mengungkapkan bahwa apresiasi yang diterima dari atasan dan manajemen belum cukup baik. Penghargaan non-materiil seperti tunjangan kesehatan, hari libur, dan cuti dirasa telah sesuai. Akan tetapi, terkait dengan insentif yang diterima, 89,09\% perawat non-PNS mengeluhkan tidak sesuainya besaran yang diterima dengan kinerja yang dikerahkan. Hal tersebut ditambah dengan tidak tepatnya waktu pemberian insentifnya (94,55\%).

Menurut Keputusan Menteri Kesehatan Nomor 625 Tahun 2010 tentang Pedoman Penyusunan Sistem Remunerasi Pegawai Badan Layanan Umum Rumah Sakit di Lingkungan Kementerian Kesehatan, setiap rumah sakit yang telah berstatus Badan Layanan Umum (BLU) harus menyusun sistem remunerasinya (16). Berdasarkan informasi yang diperoleh dari manajemen RSD Balung, saat ini Satker BLU rumah sakit yang telah ditetapkan menjadi organisasi Badan Layanan Umum Daerah (BLUD) sejak 2013 ini belum menerapkan sistem remunerasi dalam pembagian kompensasi kepada pegawainya sebagaimana yang digunakan di lingkungan kementerian kesehatan. Remunerasi yang dimaksud di sini adalah biaya yang dikeluarkan rumah sakit yang merupakan satker BLU di lingkungan Kementerian Kesehatan sebagai imbal jasa pegawainya. Belum siapnya komponen penilaian yang diperlukan sebagai dasar penetapan insentif setiap pelayanan menjadi sebab belum dilaksanakannya sistem remunerasi di RSD Balung. Oleh karena itu, untuk memastikan pemberian penghargaan yang adil pada setiap perawat, dapat dilakukan koordinasi yang komprehensif antar profesi untuk menentukan dan melengkapi komponen penilaian remunerasi sehingga sistem remunerasi dapat segera diberlakukan.

\section{Simpulan dan Saran}

Komponen organisasi dan manajemen, hubungan kerja, pelatihan dan pengembangan, serta kebijakan organisasi dan praktiknya tidak berhubungan dengan kinerja perawat non-PNS. Sedangkan komponen desain pekerjaan dan keberlanjutan pekerjaan dan komponen penghargaan memiliki hubungan dengan kinerja perawat non-PNS. Pimpinan perlu melakukan sosialiasi kembali terkait asuhan keperawatan berikut standar kelengkapan pendokumentasiannya kepada perawat dan memvisualisasikan standar kinerja yang diharapkan serta melakukan penghitungan kembali terkait proporsi jumlah perawat yang diperlukan mempertimbangkan angka kunjungan. Untuk memastikan 
pemberian penghargaan yang adil pada setiap perawat, dapat dilakukan koordinasi yang komprehensif antar profesi untuk menentukan dan melengkapi komponen penilaian remunerasi sehingga sistem remunerasi dapat segera diberlakukan. Penelitian lebih lanjut untuk menilai kinerja menggunakan standar yang lebih komprehensif, mengetahui upaya retensi yang sesuai bagi perawat PNS dan non-PNS, serta hubungan komponen retensi dengan keterikatan (employee engagement) perawat dan hubungan keterikatan perawat dengan kinerjanya juga perlu dilakukan.

\section{Daftar Pustaka}

1. Irmawati LI. Manajemen Pemasaran di Rumah Sakit. Institut Ilmu Kesehatan-University Press; 2014.

2. Bustami. Penjaminan Mutu Pelayanan Kesehatan dan Akseptabilitasnya. Jakarta: Erlangga; 2011.

3. Wibowo. Manajemen Kinerja. Jakarta: Rajawali Pers; 2016.

4. Hafid MA. Hubungan Kinerja Perawat Terhadap Tingkat Kepuasan Pasien Pengguna Yankestis dalam Pelayanan Keperawatan di RSUD Syech Yusuf Kab. Gowa Skripsi Makassar: Universitas Islam Negeri Alauddin. 2014;

5. Netti. Hubungan antara Kinerja Perawat dengan Tingkat Kepuasan Pasien Rawat Inap di Puskesmas Kartasura. Skripsi. Surakarta: STIKES Kusuma Husada; 2015.

6. Nurhidayati. Faktor-Faktor yang Berhubungan dengan Retensi Karyawan di Rumah Sakit Prikasih Jakarta Tahun. Dalam Jakarta: UIN Syarif Hidayatullah; 2016.

7. Organization G. State of The Global Workplace (Employee Engagement Insights for Business Leaders Worldwide [Internet]. 2013.2 Tersedia pada: http://www.securex.be/export/sites/default/.content/download-gallery/nl/brochures/Gallupstate-of-the-GlobalWorkplaceReport_20131.pdf

8. Annisa A dan S, Drahen P. Pengaruh Employee Engagement terhadap Kinerja Karyawan PT. Chandra Sakti Utama Leasing. Jakarta. Skripsi. Jakarta: Universitas Indonesia; 2013.

9. Widjaja. Pengaruh Employee Engagement Terhadap Kepuasan Kerja dan Turnover Intention di SwissBelinn Surabaya [Internet]. 2014.2 Tersedia pada: http://studentjournal.petra.ac.id/index.php/manajemen-perhotelan/article/view/2836

10. Rachmah AN. Pengaruh Komitmen Organisasi, Kepuasan Kerja dan Budaya Organisasi terhadap Turnover Intention Pada Karyawan Hotel Mutiara Merdeka Pekanbaru. Pekanbaru: JOM Fekon; 2017.

11. Prawitasari A. Faktor-Faktor Yang Mempengaruhi Turnover Intention Karyawan Pada PT. Mandiri Tunas Finance Bengkulu [Internet]. 2016. Tersedia pada: https://media.neliti.com/media/publications/55204-ID-none.pdf

12. Astuti DP dan P, Sibarani M. Pengaruh Kompensasi terhadap Retensi Karyawan Melalui Kepuasaan Kerja dan Komitmen Afektif Pada Beberapa Rumah Sakit di Dki. Jakarta. September 2014;527:12.

13. Buchbinder SB da. S, H N. Buku Ajar Manajemen Pelayanan Kesehatan (terjemahan). Jakarta: EGC; 2014.

14. Mathis RL da. JJH. Human Resource Management. 13 ed. USA: South-Western Cengage Learning; 2010.

15. Kementerian Hukum dan HAM Republik Indonesia. Undang-undang Nomor 5 Tahun 2014 tentang Aparatur Sipil Negara [Internet]. 2014. Tersedia pada: https://luk.staff.ugm.ac.id/atur/UU52014AparaturSipilNegara.pdf

16. Indonesia KMKR. Pedoman Penyusunan Sistem Remunerasi Pegawai Badan Layanan Umum Rumah Sakit [Internet]. 2010. Tersedia pada: https://www.scribd.com/document/377341918/KEPMENKES625-TH-2010-TTG-PEDOMAN-REMUNERASI-pdf 